\title{
Women's engagement in and outcomes from small-scale fisheries value chains in Malawi: effects of social relations
}

\author{
Chikondi Lydia Manyungwa ${ }^{1}$ (D) $\cdot$ Mafaniso M. Hara $^{2} \cdot$ Sloans K. Chimatiro ${ }^{3}$
}

Received: 25 May 2019 / Accepted: 13 October 2019 / Published online: 10 November 2019

(C) Springer-Verlag GmbH Germany, part of Springer Nature 2019

\begin{abstract}
Women play an important role within small-scale fishing communities in sub-Saharan Africa through engaging in fish value chain activities and contributing to household food security and income. There is, however, little empirical information about the nature of women's engagement in small-scale fishery value chains and the outcomes of that engagement especially in Malawi, our study country. This study addresses the gap by examining (1) the ways in which women participate in fish value chains; (2) the outcomes of their participation at individual, household, and community level; and (3) how social relations influence the participation and the outcomes obtained. The study adopted a case study approach and draws upon qualitative data from the two small-scale fisheries in Msaka on Lake Malawi and Kachulu on Lake Chilwa. The research applies a social relations approach in the line of Kabeer, in examining women's participation and outcomes of participation within the small-scale fisheries. Our study reveals that women provide significant social and economic benefits to their families and the broader community as they participate as processors and traders with a few participating at the production node as gear owners. The study also finds that women encounter challenges that may have potential to negatively affect their engagement in the small-scale value chains including gender-based discrimination as some women are restricted by their husbands to engage in the intermediary role especially at Kachulu; the few women who join the crew fishing face social exclusions, poor working conditions, care burden that limits women's time to actively participate in value chain activities. The study highlights the social norms associated with hierarchical husband-wife relationships have negative effects on women's participation and the outcomes derived in the value chain activities. This research adds to the body of work that examines issues of social relations and their impacts on the well-being and roles of women in small-scale fisheries.
\end{abstract}

Keywords Women $\cdot$ Value chains $\cdot$ Small-scale fisheries $\cdot$ Social relations $\cdot$ Malawi

\section{Introduction}

Fisheries play a significant role in human well-being, particularly for the poor in developing countries where $97 \%$ of fishers live (Allison and Ellis 2001). The small-scale fisheries sector is gaining wider international attention through the development of the Voluntary Guidelines for Securing Sustainable Fisheries in the context of Food Security and Poverty Eradication (henceforth SSF Guidelines) (FAO 2015; Lentisco and Lee Ulric

Chikondi Lydia Manyungwa cpasani@gmail.com

1 Department of Fisheries, Lilongwe, Malawi

2 Institute for Poverty, Land and Agrarian Studies (PLAAS), University of the Western Cape, Cape Town, South Africa

3 WorldFish Centre, Lusaka, Zambia
2015). However, some small-scale fisheries are under extreme pressure from overfishing, suffer from poor governance, and face new threats as a result of climate change (Allison et al. 2009; Beddington et al. 2007; Coulthard 2012). Meeting these challenges effectively is intrinsically reliant on fostering adaptation and innovation among fishing communities.

Small-scale freshwater pelagic fisheries are important to millions of people in sub-Saharan Africa providing livelihoods and nutritional security (Chiwaula et al. 2012). Malawi lies within the Great Lakes region and has rich aquatic resources. The fisheries sector in Malawi plays an important role in the livelihoods, nutrition, and food security of rural communities (FAO 2005). In 2017, according to the frame survey report, the sector directly employed an estimated 63,023 fishers of which 5\% were women involved as gear owners. The small-scale subsector is widely spread through the country's fishable waters and this is where women are dominant (Department of Fisheries 2017). 
Williams (2008) posit that women play a critical role in every link of the value chain in small-scale fisheries although their best known roles are in processing and marketing of fish and other fishery products. The Small-Scale Fisheries Guidelines was a milestone for recognizing gender and also in augmentation with the FAO Code of Conduct for Responsible Fisheries which was silent on women and gender. Women across generations and occupational status are intrinsically part of dynamics in fishing communities (Mtunda et al. 1998). In Malawi, women in small-scale fisheries play key roles in fish processing and marketing (FAO 2013). The involvement of women in these activities generates supplementally income to support their families. Despite their involvement in these crucial activities in the fish value chain, their representation in governance structures and decisionmaking processes is very limited (Fernandez et al. 2005).

It is recognized that the involvement of women in the smallscale fisheries sector is also influenced by social relations. Ribeiro and Zwirner (2010) note that the importance of social relations in value chains is becoming increasingly recognized. Social relations influence peoples' motives, relations and behavior; hence, people are relational and influenced (Ostrom 2000) depending on the diversity of institutions, physical and cultural settings in which they interact. Hence, social relations denote a range of positive or adverse outcomes on interactions and social networks (Pawar 2006). Schmitz (1999) contends that understanding social relations among actors is important for successful functioning of value chains. However, the engagement of women in the small-scale fisheries value chains and influences of social relations on their engagement remain poorly understood.

There is a growing recognition of the importance of gender to developing resilient fisheries, and more studies have been added (Harper et al. 2013; Kleiber et al. 2015; Frangoudes and Gerrard 2018). In spite of this, there are as yet relatively few empirical analyses of gender related to specific fisheries like the Malawi small-scale fisheries. This study contributes to addressing this gap by investigating women's participation, outcomes of such participation, and influences of social relations in the value chains of small-scale fisheries in Malawi. The study adopts a case study and qualitative method approach and investigated small-scale fisheries value chains at two sites: Kachulu on Lake Chilwa and Msaka on Lake Malawi. The research was part of a 4-year European Unionfunded Fish Trade project across sub-Saharan Africa which investigated intraregional fish trade and food security (WorldFish 2013).

This paper seeks to raise an understanding of social relations that underpin small-scale fisheries value chains. We addressed the question of how social relations affect participation, engagement and outcomes of women who participate in small-scale fisheries value chains drawing from small-scale fisheries. A social relation approach is used to examine women's participation and outcomes of their participation within the small-scale fisheries.

The social relations approach as developed by Kabeer (1994) draws on structural feminist roots locating the family and household within the network of social relations connecting them to the community, markets, and the state. The social relations approach, Kabeer (1994) asserts that development is a process of increasing human well-being (survival, security, and autonomy) and not just economic growth or increased productivity. In this paper, the social relations approach is applied in three main ways. First, while the study includes assessment of gendered roles as a foundation, it specifically goes beyond roles to focus on how relations shape engagement as well as outcomes. Second, it incorporates a nested, multi-scale approach that situates women within the household, the community and markets. Third, the study reflects the social relations approach emphasis on development as multi-faceted dimensions of well-being. We follow a "social relational perspective" on gender relations (Kabeer 1989; Razavi and Miller 1995) because gender frameworks that focus only on roles, resources, and decision-making do not adequately capture the complexity of gendered social change (Locke and Okali 1999). The social relational perspective on gender gives attention to structures of discrimination (such as gender norms that frame fishing as a man's role or prevent women from holding property) as well as to women's and men's ability to negotiate within (and around) the expectations arising from these structures (namely their "agency"). This approach means focusing on men as well as women and illuminating the tensions and trade-offs that they make in their everyday lives (Cole et al. 2015). Social interactions among actors have been identified as important to successfully functioning value chains (Schmitz 1999). Further to this, social relations determine peoples' roles, rights, responsibilities, and claims over others and that institutions can produce and maintain social inequalities.

For this paper, we use the network around the production of a Barbus paludinosus (matemba) for Kachulu on Lake Chilwa and Engraulicypris sardella (usipa) for Msaka on Lake Malawi as the small-scale value chains and the networks as the focus. Specifically, we look at the ways women are involved in the value chain and network activities and the outcomes of their involvement at these two small-scale fishing communities. For the two fishing communities studied here, women engagement had important and differentiated effects on socio-economic well-being of the households and community.

Specifically, the paper examines (1) the ways in which women participate in the fish value chains; (2) the outcomes of their participation at individual, household, and community levels; and (3) how social relations influence the participation and the outcomes among women who engage in the smallscale fish value chains and networks. 


\section{Methodological considerations}

\section{Data collection, case study selection, and methods}

The study adopted a case study approach and qualitative methods to investigate women's involvement in small-scale fisheries value chains and social relations among actors. The benefits are that a case study approach seeks to understand (not measure) people's experiences with the idea of providing careful descriptions of life as it is lived and experienced (Yin 1994). The study investigated two small-scale fisheries on two water bodies in Malawi, Lake Malawi and Lake Chilwa, which represent distinct value chains of smallscale fisheries. The study used two fishing communities/ villages: Kachulu in Lake Chilwa and Msaka in Lake Malawi (Fig. 1). The cases were selected as representing small-scale fisheries based value chain activities in which both men and women are involved. In addition, the two communities represent diversity in environmental, governance, and social characteristics.

Lake Chilwa is an inland drainage lake whose size recedes by more than $50 \%$ annually and completely dries up periodically (Hara and Njaya 2014; Chiwaula et al. 2012). Lake Chilwa is one of the most densely populated areas in Malawi with density of roughly 321 people per square kilometer (NSO 2008). The diverse ecosystem of the lake allows it to support a variety of valuable common property resources

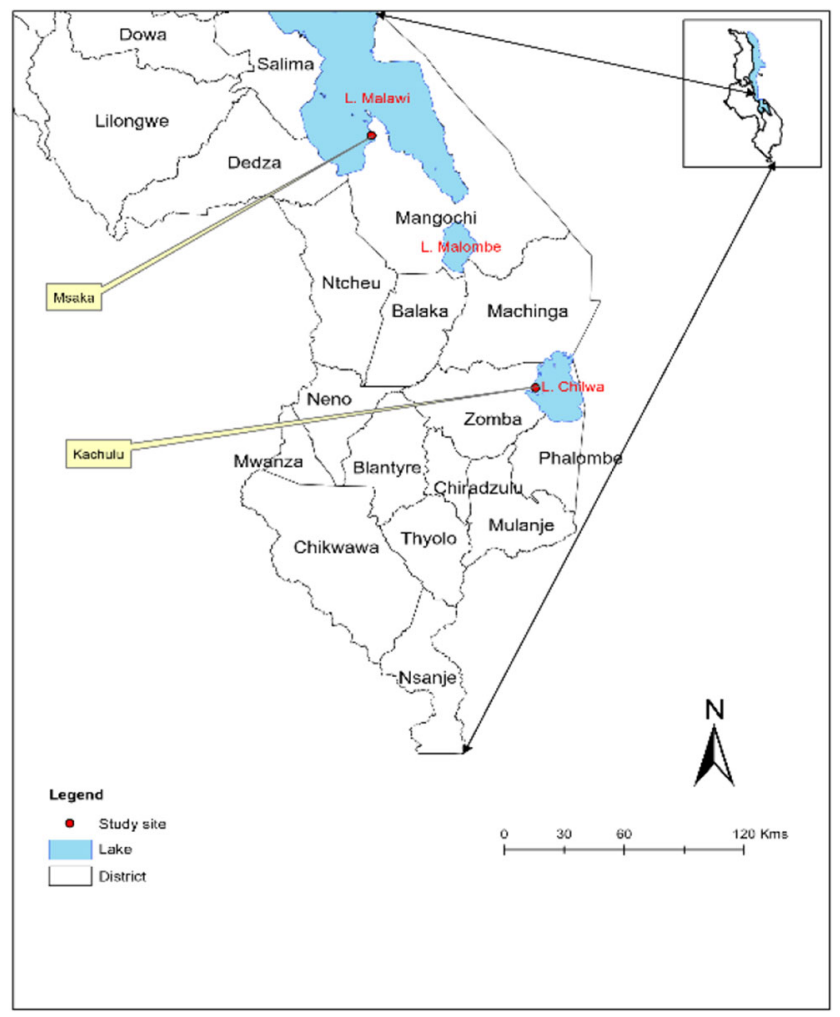

Fig. 1 Map of Malawi showing location of Kachulu and Msaka fishing communities (Manyungwa et al.) and livelihood activities such as dry season farming and bird trapping apart from fishing (Hara and Njaya 2014). The smallscale fishery is dominated by three species-Barbus paludinosus (matemba), Oreochromis shiranus chilwae (makumba), and Clarias gariepinus (mlamba) and are threatened largely by climate change (Chiwaula et al. 2012). Women are involved in the fishery, particularly in the value chain of Barbus paludinosus species (Chiwaula et al. 2012). The ethnic community practices a matrimonial system of marriage.

Lake Malawi's small-scale fisheries are highly complex, are scattered, and mainly operate between 0 and $20 \mathrm{~km}$ from the shore. The main target fish species for small-scale fisheries, depending on the fishing gear, are Oreochromis species (chambo), Haplochromis species (kambuzi), Engraulicypris sardella (usipa), Copadichromis species (utaka), Bagrus meridionalis (kampango), and Clarias gariepinus (mlamba) (FAO 2005). A patrimonial system of marriage is practiced by the largely Tonga ethnic community that had settled at Msaka from Nkhata Bay from the middle of the last century.

In this study, the focus was on two fish value chains where women are engaged in: Barbus paludinosus (matemba) in Lake Chilwa and Engraulicypris sardella (usipa) in Lake Malawi.

The research drew on three methods of data collection, namely key informant interviews (KII), semi-structured individual interviews (SSII), and focus group discussions (FGDs). The field work was conducted over 6 months between January and June in 2017. Verbal consent was obtained from participants before commencement of interviews.

KII were undertaken with local experts to obtain expert opinions on the level of women's participation in the local fishery value chains and on village-level characteristics such as ethnicity, religion, cultural practices, and challenges. Two KII were conducted in each community/village with a local leader and a fisheries extension officer. SSI (7 in Kachulu and 8 in Msaka) and FGD ( 2 in Kachulu and 3 in Msaka) were then conducted with men and women in each village. SSI obtained information at individual and household levels on the respondent's participation in fish value chains, outcomes of their participation, and how social relations influence participation and outcomes. FGDs were undertaken to gain insights into how social relations outcomes and obstacles affect women in the fish value chain at the community level. Focus groups were guided by the same questions and themes used for SSII.

Participants were purposively selected with the guidance of the fisheries extension staff to capture a range of actors actively involved in the fish value chains. The maximum variation sampling technique (Palinkas et al. 2015) was used involving fishers, processors/traders, fish collectors, local leaders, and extension staff. According to Palinkas et al. (2015), the basic principle behind the maximum variation sampling technique is to gain greater insights into a phenomenon. This technique enabled the 
understanding of the social relations within the value chains from different actors. Interview notes were transcribed in line with the interview and were thematically analyzed using inductive process of coding (Berg 2004). There were some overlaps between SSI and FGD as some participants who participated in SSI were also involved in the FGDs. The FGDs were interactive and took between 30 minutes to one and half hours.

Interviews were conducted in local language and results were translated in English. Ethical clearance was sought through the University of the Western Cape in South Africa through the faulty of Economics and Management Sciences. Data from the KII, FGD, and SSII were typed and stored electronically and hard copies of hand-written notes from the field were also kept. The respondents' answers were organized, transcribed, and analyzed deductively by using the pre-determined thematic areas of participation, outcomes, and the social relations on participation and the outcomes of participation. The analysis took into account intersectionality aspects looking at marital status, age, and sex within the limits of a small study.

\section{Empirical findings and analyses}

The results of the study are analysed and presented on the three pre-determined themes of investigation by case study site, namely participation in value chains, outcomes of participation in value chains, challenges women face as they engage in value chain activities, and concluding with how the social relations impact participation and the outcomes.

\section{Participation in value chains}

At Kachulu, focus group discussions and semi-structured interview participants identified four major nodes where women participate in the value chains for Barbus species which included production, intermediary (local brokers), local processors/traders, and exporters. The production node involves gear/boat owners and actual fishing ${ }^{1}$ is dominated by men with only an estimated $7 \%$ of women participating in this node as gear owners: "women participation is very low in production" (fisheries extension officer, Kachulu).

The intermediary actors are locally known as "macheucheu" and their role is to broker the sale of fish between fishers and processor/traders for a fee (based on a determined amount of Kwacha per number of tins sold/brokered for). Women dominate the intermediary node with $70 \%$ of actors estimated as female (fisheries extension officer, Kachulu). One male respondent noted: "We make sure we allow only women from within the community to participate in this role because we have noted that a lot of women are single and as a result they need financial

\footnotetext{
1 The Department of Fisheries in Malawi defines a "fisherman" as the "gear owner." In this study, we refer to gear owners and crewmembers as "fishers"
}

income to support their families. Allowing them to participate in this role provides them the chance to earn some money" (male gear owner, Kachulu).

At Msaka, the intermediary actors are called jolova. At Msaka, it was reported that, once fish is caught, the gear owner sells the fish to the spouse and also in some instances to spouses of crewmembers. The wife then processes the fish before selling it to a trader or taking it to the urban markets. It was further indicated that "In some instances, the wife might choose to sell the fish to the processor/trader rather than processing it herself' (male fisher, Msaka).

At both case study sites, women were also involved in processing and trading fish. Barbus species were reported to be sundried, brined, and/or smoked. While Engraulicypris species is either sundried immediately or parboiled before it is sundried. At Kachulu, women processors were reported to sell fish to traders at the landing beach, but were predominantly reported to take and sell at upland markets (fisheries extension officer, Kachulu). One female processor reported: "We also sell processed fish to traders right at the beach" (female processor, Kachulu). While at Msaka, it was reported by the processors/traders that they sometimes wait before going straight to market until they have a large enough consignment.

A few women processors/traders at both sites were also involved in the export node. Women processors at Kachulu reported selling fish across into Mozambique through the Nayuchi border at Ncuamba market or sometimes selling to buyers from Mozambique through the Mulanje border at Limbuli market. A few women processors also reported taking fish to Zambia and the Democratic Republic of Congo to sell. One female fish exporter said, "Once I have accrued a big enough consignment, I take the fish to Mozambique using Ncuamba border in Phalombe and I sell the fish on wholesale" (female fish exporter, SSI, Kachulu). Women in Msaka are also involved in exporting the fish to foreign markets. The women traders from Msaka mentioned that "we take our fish for sell to Zambia, Tanzania, and South Africa". "Normally when we go there, we sell on wholesale and come back" (female fish processor/trader, Msaka). Figure 2 shows the flows of fish from the study sites to various destinations.

\section{Outcomes of participation in value chains}

\section{Household decision-making}

At both sites, it was reported that women and men at household level engage in joint decision-making on the use of the money that accrues from participating in the value chain activities. At Kachulu, female fisherfolk revealed that through engaging in fish value chain activities, they were able to become more involved in household finance decision-making. However, one female fish processor noted that "since I started engaging in fish processing and selling fish, I have a say in 


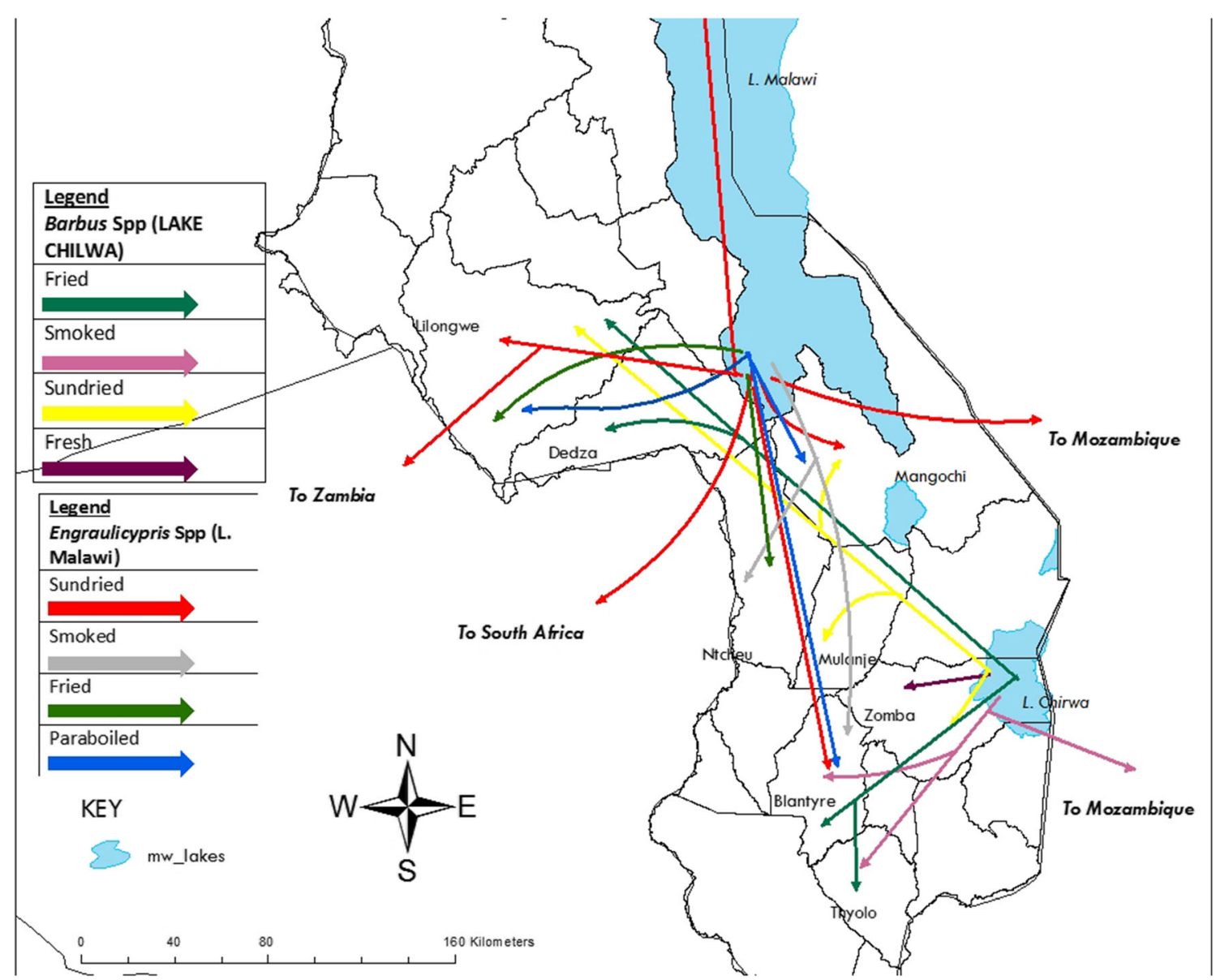

Fig. 2 Map showing flows of fish from Kachulu and Msaka to various destinations (Manyungwaet al.)

how the money is used within my household compared to the time when I was not doing anything that could bring income to the household" (female fish processor, Kachulu). Whereas at Msaka, women said that the joint decision-making and planning of the use of the income is a big step forward for the partnership between spouses, the position of women in the family and family life as a whole. One female respondent stated that "while women discuss with husbands on money matters this does not necessarily mean that men and women are at the same level" (female processor, Msaka). Women reported of the freedom to discuss issues of finances with their husbands and it was appreciated that transparency in money matters has increased with positive consequences for men and women alike. Figure 3 shows the schematic presentation of the outcomes at household.

\section{Food and nutrition outcomes}

The study collected information on how households spend the income from value chain activities. Evidence from women's views show that they spend large fractions of the income acquired from value chain activities to improve household nutrition. At Kachulu, female respondents reported ability to buy food. One female respondent further explained the value to household food security, "my participation in fish value chain activities has enabled my household to become more self-reliant. I am now able to acquire food and my children eat at least twice a day. I spend two-third of the income on food and I allocate the remaining amount for other things." (female intermediary actor, Kachulu).

At Msaka, one female respondent reported that "I ensure that we keep some of the money realized from fish sales to buy food and I do that even without consultations with my husband." (female processor/trader, Msaka). In an FGD, one male respondent explained: "when women have access to finances they play a big role in providing food in the home. They have the interest of the needs of the household at heart compared to us men" (male fisher, Msaka).

\section{Personal empowerment}

The focus group discussions and semi-structured interviews revealed that participating in value chain activities contributed to women's empowerment. Few women reported improved self-esteem. Women reported to have gained leverage in household bargaining, ability to save, obtain credit, and invest. 
Fig. 3 Schematic presentation of the outcomes at household level as a result of women participating in fish value chain activities

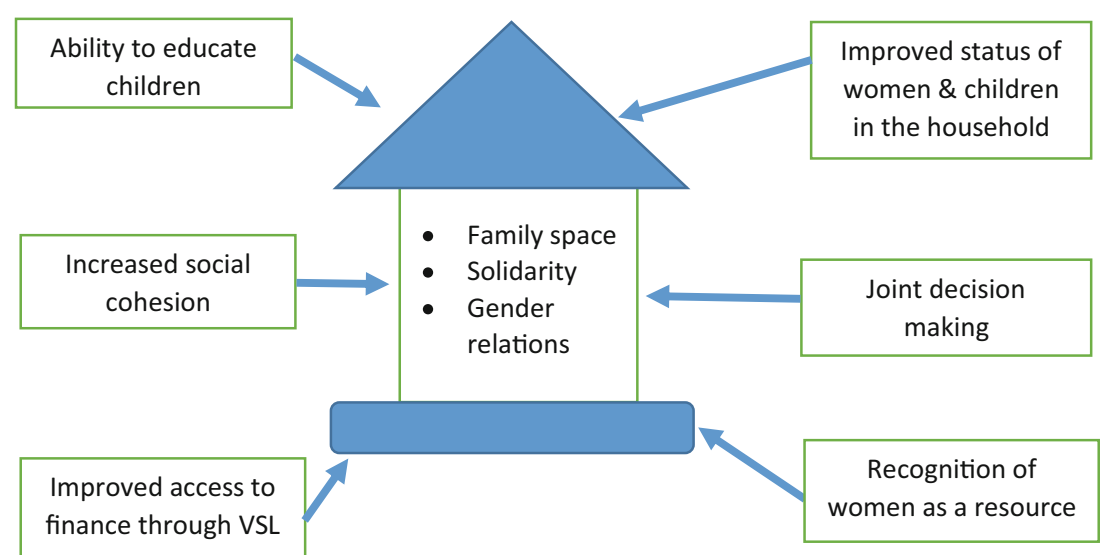

A female gear owner at Kachulu beach on Lake Chilwa reported that "I have been empowered as a result of my engagement in fishing. I have become more proactive in addressing personal problems, helping out her children as she is a single mother and improving her house. The money I get from participating in fishing activities has given me a greater latitude with male colleagues in the community who own gear. I have acquired a new public identity since I sometimes go fishing with my crew men." (female gear owner, Kachulu).

The women who play the intermediary role of "macheucheu" are either widowed or divorced. Since they are not under a hegemonic power structure, they reported that "We earn a living through participating in fish value chain activities. We have the ability to use the money to meet our needs and for the whole family" (female intermediary actor, Kachulu).

At Msaka, respondents reported that women who participate in value chain activities have acquired greater optimism and self-esteem in addressing problems. Men reported that "we see women are able to access loans through the Village Savings and Loans. In addition, they are able to get credit from colleagues without much of a hassle unlike those who do not participate in the value chain activities." (male fish processor, SSI, Msaka).

\section{Community-wide outcomes}

The study found that most of the money realized from participating in value chain activities is spent within the communities. Hence, the positive impacts are felt beyond the value chain participants and it has positive impacts. One female fish exporter explained: "once I finish selling the fish in Mozambique I bring home cooking oil, zitenje ${ }^{2}$ and spaghetti which I sell within the community. People from the community are able to acquire good stuff which I buy from Mozambique" (female fish exporter, Kachulu). A female respondent from Msaka said "once I finish selling the fish in South Africa, I order soap, cooking oil, body lotions which I

\footnotetext{
$\overline{{ }^{2} \text { Zitenje refers to cloth wrapper used by women }}$
}

bring back home and sell to my community members." (female fish exporter, Msaka).

One male respondent acknowledged that "women are able to join contribution based networks and informal financial networks such as Village Savings and Loans (VSLs) which is also having a big impact on the circulation of money at the community level" (male processor, focus group discussion, Kachulu). It was also found that participation in VSLs is more than just an issue of money. Female respondents hinted that "participation in VSL strengthens social cohesion as contribution of shares makes individual dreams come true". "We are able to borrow and invest in business and other things" (female processor, Kachulu).

At Msaka, the study revealed that with the income realized from value chain activities, women are able to engage in petty trade activities including vegetable trading, and other small businesses such as making and selling doughnuts on makeshift stands. One female FGD respondent elaborated that "these businesses were more of survivalist in nature, as the money contribute to continued supply of an income for households" (female fish processor/trader, Msaka).

\section{Challenges faced by value chain actors}

The study also examined challenges to women participation in value chain activities. The study found that women faced similar obstacles at both Msaka and Kachulu. The study identified the main obstacles as gender-based discrimination in the value chain, environmental factors, poor working conditions, care burden, inadequacies in knowledge on trade-related policies and socio-cultural factors.

\section{Gender-based discrimination in the value chain}

The study found that married women are restricted from participating in the role of intermediary actors. One male respondent said, "I cannot allow my wife to participate in the role of "macheucheu." "This role is not very productive. People make very little in a day and we see most 
women engaging in sexual relationships with fishers to access the fish, unlike the processors who have the money to buy the fish." (male gear owner, Kachulu). At Msaka, married female respondents in FGDs reported that "we are sidelined by the fishers who when fish catches are low, they chose to prioritize selling the fish catch to traders from outside the communities with the view of selling at a higher price. As a result, we are pushed out to make room for the traders who are predominantly male" (married female processor, Msaka). One could also argue that divorced and single women from outside Kachulu and women that are not spouses of the gear owners and crew members at Msaka are discriminated against when it comes to playing the intermediary fish buying role. $\mathrm{Theft}^{3}$ of money by crewmembers was also stated by female gear owners.

\section{Environmental factors}

Respondents lamented of uncertainties arising from dwindling fish stocks. They said that livelihoods are insecure as fishing is often unpredictable. Fishers said, when they go to a fishing ground and find that there are no fish, they migrate to another fishing site. This is costly in the end.

Women respondents said the uncertainties due to dwindling stocks have negatively affected most of the women gear owners. Most of those who were interviewed used to operate a minimum of 2 to 7 gears but due to the decline in fish catches, some resorted to selling their gear and only remained with one. This has affected their livelihoods heavily as they only rely on one gear. One woman in a semi-structured interview in Kachulu lamented that "I used to have four matemba seine nets (zilimira) but now I only have one. I had to sell the other due to inadequate catch. When I had the four zilimira I once bought a pickup with finances from fishing which was used for transporting fish to inland markets. With the decline in catches I sold my gear including the pickup and now I am struggling to make ends meet with the single gear which I remain with" (female gear owner, Kachulu).

Fishers explained their livelihood vulnerability through metaphors. For instance, one FGD respondent said, "ndalama za usodzi zili ngati madzi" meaning that "money realised from fishing activities flows out like river as the money does not stay in hand." (male fisher, Kachulu)

Respondents pointed to the challenge of climatic variability which affects the Lake Chilwa and sometimes jeopardizes the ability of the households to sustain their household economy. "We are challenged by the climate variability which affects the lake as it sometimes dries up. In

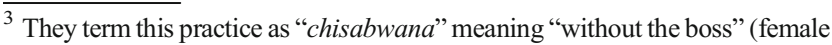
gear owner, Kachulu).
}

addition, the southerly winds are no longer predictable nowadays and that affects us in terms of the number of days that we go fishing" (male gear owner, Kachulu).

At Msaka, fishers reported of variations in catches. FGD respondents said, "The fishers will get K200,000 out of the fish catch he makes today, tomorrow he goes back to fish and he doesn't have anything, and the K200,000 he had yesterday is all gone. It is unfortunate that the money that we fishers get from the fishing activities cannot be managed properly." (male fisher, Msaka). "Those fishers operating trawlers are fishing in areas where we are supposed to fish and when we go to fish we find that they have already swept much of the fish. This has serious implications on our affairs as small-scale fishers" (male fisher, Msaka).

\section{Poor working conditions}

At Kachulu, both men and women value chain participants raised a concern over the conditions that they work in. They said "we wade through dirty water to get to the place where the boats dock" (female intermediary, Kachulu). One woman FGD participant said, "as you can see the way the water looks like, we walk in this muddy dirty water to get to where the boats dock and sometimes we walk with children on our backs and as we scramble for the fish some dirty water spills in our mouths and on our children. This is not healthy at all." (female intermediary, Kachulu). Figure 4 shows women buying fish and the poor conditions in which they work. Fish processors reported the lack of proper shed for handling the fish and where to sit while waiting for the boats to land. "We have to sit for long hours in hot sunshine to wait for boats to land to buy fish" (fish processor, Kachulu).

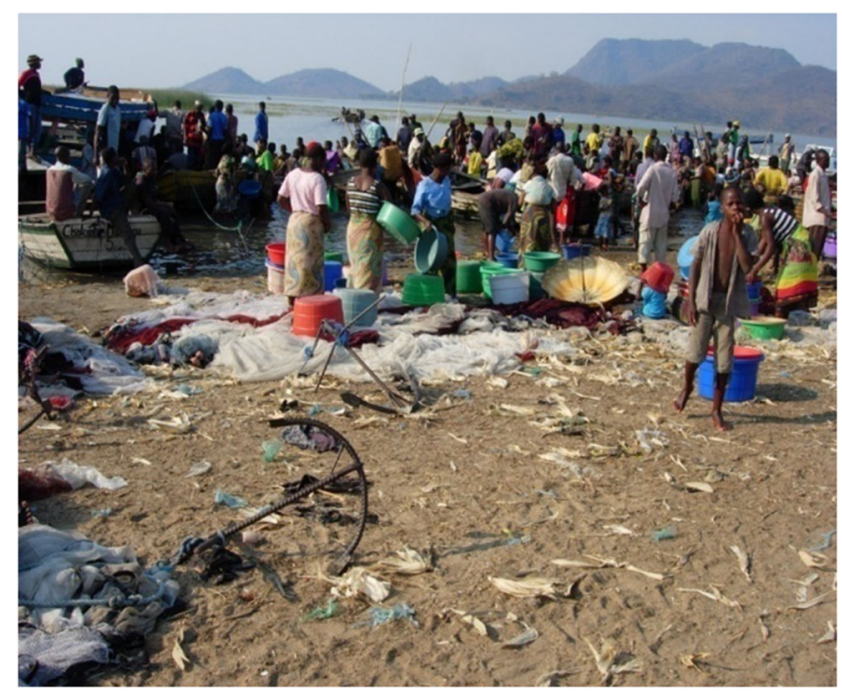

Fig. 4 Women working in a poor environment 


\section{Care burden}

Fishing communities are characterized by high school drop outs and therefore low levels of education. The girl child has been a victim of this high school dropout. The study found that early marriages were still pervasive. Respondents had this to say "while we are striving to support our families, our daughters are getting married at an early age. We may be seen to be condoning the practice but the effects still come back to us as mothers." (fish processor, Kachulu). It was reported that "as the girls are married at an early age, we as mothers are left with the burden of child care for the young ones since the girls leave their children with us and opt to go out to urban areas to seek domestic work, which limits our participation in value chain activities" (female intermediary actor, Kachulu). At Msaka, semi-structured interviews revealed that women are also negatively affected by the responsibilities of child care. If you have a small child, one female processor/trader explained: "you have to travel with that child when you go the markets and sometimes it is not easy since sometimes we take risky means of transport like getting on top of pickups and lorries." (female processor, Msaka).

\section{Inadequacies in knowledge on trade-related policies}

Most women who are involved in fish exports reported that they are not aware of the trade-related policies let alone cross border policies. The main reason which was cited was the lack of public sensitization on the available policies.

A fish processor who is not a member of the processing association said "we lack sensitization on the available policies as such we just do things without following proper guidelines." (fish processor, Kachulu).

Notwithstanding the challenge related to knowledge in trade policies, women who are members of the processing associations expressed satisfaction with the benefits of participating in such organizations. They reported that "we got the information through the sensitization by WorldFish which brought the information to their knowledge through the association" (fish processor, Kachulu). The women reported that by being members of processing associations, they have access to capacity building in terms of skills, marketing information, and sometimes ready markets for the processed fish.

\section{Socio-cultural factors}

The study identified two main social-cultural factors that affect and hamper women participation in value chain activities, namely domestic violence and polygamy.
Domestic violence was reported to be prevalent at both case study sites. Respondents reported that most women in families where domestic violence was prevalent have limited ability to participate in value chain activities. One respondent explained: "mzimayi sumakhala ndi ufulu otenga nawo mbali pa zochitika ku Nyanja. Ukamayenda umaona ngati aliyense akudziwa zimene ukukumana nazo mnyumba mwako. Umaona ngati aliyense akuyang'ana iwe" ("As a woman you feel degraded and you cannot actively participate in value chain activities. It is like everyone knows what goes on around you and within your family. Your status is undervalued. You become a laughing stock") (intermediary actor, Kachulu).

Polygamy was identified as another obstacle. It was reported by women interviewees that polygamy is widespread in the fishing communities. They reported that it had serious negative effects on women in particular. For instance, women interviewees at Kachulu said "a woman may be involved in fish processing and trading and the husband gets some of the money to spend it on the other co-wife. This can be demoralizing." They said that "we feel that women in polygamous marriages and relationships had more problems compared to women in monogamous marriages and relationships" (female processor, Kachulu).

\section{Discussion and conclusions}

Social relations within the household and community are culturally determined (Batliwala 2007). Women's roles and involvement in small-scale fisheries have often been overlooked and undervalued (Chuenpagdee et al. 2006 and Harper et al. 2013). The social relations approach was useful for the study as it helped in understanding the social relations within the household and between the actors in the fish value chains. In particular, it presents respondents' self-identified areas of outcomes, which include but go beyond economic outcomes to include empowerment-related outcomes at the individual level, as well as outcomes related to household food security and well-being. In the two fishing communities studied here, it can be acknowledged from the results that women play an important role in the small-scale fish value chains and their involvement had made a difference in terms of outcomes at individual, household, and community levels. In addition, engagement has brought more positive outcomes for women. Intrahousehold relations improved as a result of women participating in value chain activities.

From the case studies, very few women were found to be involved at the production node as gear owners while the majority tend to be relatively well integrated in the 
post-harvest nodes of the value chains of Engraulicypris species (usipa) and Barbus species (matemba). This finding is similar to that of Coles and Mitchell (2010) who reported that engagement in post-harvest chain nodes requires limited resources like finances and business skills. The few women who are involved in the production node as gear owners do not have full control of where to catch fish since they engage men as crew to operate their fishing units. In line with Sari et al. (2017), at both case study sites, women's engagement and outcomes are influenced by norms regarding appropriate spaces of engagement (household and beyond the household), and the various gender relations that reinforce these stereotypes and norms. Socially acceptable exceptions (stepping out of accepted gender roles and spaces) are found to occur mostly in the case of women engaging in the node of production node as gear owners and in particular at Kachulu where one woman joins her crew member to go fishing.

The study has revealed that women play a crucial role especially as intermediary actors in the fish value chain between the production and processing/trading levels. This activity is an important source of income for women who are divorced, single, or widowed as they earn their living from brokering the sale of fish between fishers and processors/traders. It is important to note that though the women have minimal returns from participating in the intermediary roles, they said these activities reduce livelihoods vulnerability as they safeguard households against slipping deeper into poverty. In addition, the women argued that these activities have contributed to improving the lives of the women through access to incomes.

Their role is not adequately recognized by government and development agencies as there are no support services targeted to such actors. The women have limited access to information including from government support programs and as a result, no support services have been provided for such actors. This finding is similar to that of Albert et al. (2014).

A significant household-scale finding surfaced in both cases regarding gendered roles (and relations) in decisionmaking, including strategic decisions related to food and nutrition provisioning. Through their involvement in value chain activities, women play an important role at household level generating income which they use for food and nutrition. In relation to this, it was found through the case of Msaka that husbands invest less on food and nutrition. This is similar to the findings by Kleiber et al. (2015) which shows gender differences in how men and women invest in food security. Differences emerged in decision-making power between men and women and this is similar to findings by Sari et al.
(2017) in their study conducted in Cambodia where there was a noticeable manifestation of gender norms that considers men as the head of household and final decisionmaker. Even though Kachulu is a matrilineal society, prevalence of patriarchal values is observed. Men still dominate decision-making as to which value chain activities their wives have to get involved with. The study established that some men do not allow their wives to participate in the intermediary role of fish brokerage. This results in loss of economic opportunities for women and this can have long-lasting socio-economic effects on the families and communities.

With regards to community-wide outcomes, the study found that most of the money realized from participating in value chain activities is spent within the communities in both case study communities. Hence, the impact is felt beyond the value chain participants and it has positive impacts on the local markets. It was reported that there is a tendency of a boost on the local businesses once fish sales are done despite surges in fish supplies. It was also evident that participation of women in fish exports has led to diversification of goods offered on the local markets. In addition, women's participation in value chain activities enabled women to access informal financial networks such as Village Savings and Loans and helped to promote social cohesion both within the community and at household levels.

Women and men face numerous challenges as they participate in small-scale fisheries value chain activities. In both case study sites, the key obstacles identified include gender-based discrimination, environmental factors, poor working conditions, care burden, inadequacies in knowledge on trade-related policies, social exploitation, and socio-cultural factors. It was found that the level of knowledge on trade-related policies among value chain participants especially those involved in fish exports is generally poor. This is in tandem with Southern Africa Trust (2018) in their study in terms of experiences and challenges of women in the SADC which highlighted that women involved in informal cross-border trade lack knowledge of trade policies.

The results indicate the dynamism of gender relations as a constituent of broader social relations. Further, it highlights the important role that women play to contribute to self-empowerment, improved household well-being, and community wider gains. The study has also brought out some key challenges requiring attention to be resolved. Lessons from our case studies include the importance of supporting women with gender-based violence awareness raising to curb the obstacle on domestic violence which women in Kachulu experience. 
Acknowledgments Special thanks go to Cynthia McDougall and Fiona Simmance for their critical review of the drafts for the paper. The authors also extend thanks to all respondents for participating in this study, as well as all Department of Fisheries staff for field work logistical assistance.

Author contributions The first author conducted the field research and data analysis and wrote the initial manuscript. The two co-authors contributed to the manuscript by providing analytical and theoretical input.

Funding information This work was undertaken as part of the CGIAR Research Program on Fish Agrifood Systems (FISH). Funding for this study was provided by European Union-funded Fish Trade Progamme implemented through the Lusaka Zambia office. The research was also in part funded by the Gender Equality Studies Training (GEST) programme of the University of Iceland.

Data availability The data underpinning the findings of this research are not yet publicly available in any consolidated form.

Compliance with ethical standards The research was approved as part of the lead authors $\mathrm{PhD}$ studies by the Humanities and Social Science Research Ethics Committee of the University of the Western Cape, with ethics reference number HS/16/1/5. Verbal consent was obtained from participants before commencement of interviews. Ethical clearance was sought through the University of the Western Cape in South Africa through the faulty of Economics and Management Sciences.

Competing interests The authors declare that they have no competing interests.

Disclaimer The views and opinions expressed herein are those of the authors and by no means those of the European Union, WorldFish, nor GEST programme.

\section{References}

Albert, Joelle A., Doug Beare, Anne-Maree Schwarz, Simon Albert, Regon Warren, James Teri, Faye Siota, and Neil L. Andrew. 2014. The contribution of nearshore fish aggregating devices (FADs) to food security and Livelihoods in Solomon Islands. PLoS One 9 (12): e115386 Public Library of Science.

Allison, E.H., and F. Ellis. 2001. The livelihoods approach and management of small-scale fisheries. Marine Policy 25: 377-388.

Allison, E.H., A.L. Perry, M.-C. Badjeck, W. Neil Adger, K. Brown, D. Conway, and N.K. Dulvy. 2009. Vulnerability of national economies to the impacts of change on fisheries. Fish and Fisheries 10: 173-196.

Batliwala, S. 2007. Putting power back into empowerment (online) available https://www.opendemocracy/article/puttin power back into empowerment. Accessed 23 Nov 2018

Beddington, J.R., D.J. Agnew, and C.W. Clark. 2007. Current problems in the management of marine fisheries. Science 316: 1713-1716.

Berg, B.L. (2004) Qualitative Research Methods for Social Sciences, 5th Edition, Pearson Education, Boston.

Chiwaula, L. Jamu, D. Chaweza, R. and Nagoli, J. 2012 The structure and margins of the Lake Chilwa fisheries in Malawi: a value chain analysis. World Fish Centre Project Report 2012-12

Chuenpagdee, R., M. Lisaliguori, L.D. Palomares, and D. Pauly. 2006. Bottom -up global estimates of small-scale marine fisheries catches. Fisheries Centre Research Reports 14. https:// doi.org/10.14288/1.074761.
Cole, S.M., R. Puskur, S. Rajaratnam, and F. Zulu. 2015. Exploring the intricate relationships between poverty, gender inquality and rural masculinity: a case study from aquatic agricultural system in Zambia. Culture, Society and Masculinity 7: 154.

Coles, C. and Mitchell, J. 2010 Gender and agricultural value chains - a review of current knowledge and practice and their policy implications Overseas Development Institute London UK http://www.fao. org/3/a-am310e.pdf. Accessed 28 Nov 2018

Coulthard, S. 2012. Can we be both resilient and well and what choices do people have? Incorporating agency into the resilience debate from a fisheries perspective. Ecology and Society 17. https://doi. org/10.5751/ES-04483-170104.

Department of Fisheries, 2017. 2017 Annual Frame Survey Report of the Small Scale Fisheries. Fisheries Research Division

FAO, 2005. Country profile http://www.fao.org/fi/oldsite/FCP/en/mwi/ profile.htm Accessed 23 Oct 2018

FAO, 2013. Implementing improved tenure governance in fisheries. A technical guide to support the implementation of the voluntary guidelines on the responsible governance of tenure of land, fisheries and forests in the context of natural food security preliminary version, September 2013. Rome 71pp Food and Agriculture Organisation of the UN Regional Office for Asia and the Pacific Bangkok 2011 RAP Publication 2011/15 ISBN978 - 92 - 5 106934-9

FAO, 2015. Voluntary guidelines for securing sustainable small scale fisheries in the context of food security and poverty eradication. FAO Rome ISBN 978-92-5-108704-6

Fernandez-Pascal, J.J., Frangoudes, K and Williams, S. 2005. Local institutions in (Eds) Kooiman J, Bavinck, M., Jentof, S. and Pillin, R. (2005) fish for Life Intesadine Governance for Fisheries. Amsterdam University Press.

Frangoudes, K., and S. Gerrard. 2018. EnGendering change in small scale fisheries and fishing communities in a globalized world. Maritime Studies 17 (117): 124. https://doi.org/10.1007/s40152-018-0113-9.

Hara, M. and Njaya, F. 2014. Spatial and Institutional Boundaries: Access and Appropriation of Natural Resources in Lake Chilwa Floodplain. In Ramutsindela, M. (ed) Cartographies of Nature: How Nature Conservation Animates Borders, pp. 55-81. New Castle upon Tyne: Cambridge Scholars Publishing.

Harper, S., D. Zeller, M. Hauzer, D. Pauly, and R.U. Sumaila. 2013. Women and fisheries: contribution to food security and local economies. Marine Policy 39: 56-63. Elsevier. https://doi.org/10.1016/j. marpol.2012.10.018.

Kabeer, N. 1989. Resources, agency achievements: reflections on the measurement of women's empowerment. Development and Change 30 (3): 435-464.

Kabeer, N. 1994. Reversed realities: Gender hierarchies in development thought London. UK: Verso.

Kleiber, D., L.M. Harris, and A.C.J. Vincent. 2015. Gender and smallscale fisheries: a case for counting women and beyond. Fish and Fisheries 16 (4): 547-562.

Lentisco, A. and Lee Ulric, R. 2015. A review of womens access to fishing small scale fisheries FAO Fisheries and Aquaculture Circular No 1098. http://www.fao.org/3/a-i4884e.pdf. Accessed 17 Nov 2018.

Locke, C., and C. Okali. 1999. Changing gender relations: methodological challenges for gender planning. Development in Practice 9 (3): 274-286.

Mtunda, M., Namwaza. A., Nnensa, A. and Nyando, E. 1998. Women in Fishing Communities: Activities, problems, Income Sources, Average monthly Incomes and Socio-cultural parameters. Department of Fisheries, Malawi

National Statistics Office. 2008. Population and housing census report. Zomba Malawi: NSO.

Ostrom, E. (2000). Collective Action and the Evolution of Social Norms. Journal of Economic Perspectives 14(3):137-158. https://www. jstor.org/stable/2646923 
Palinkas, L.A., S. Horwitz, C. Green, J.P. Wisdom, N. Duan, and K. Hoagwood. 2015. Purposeful sampling for qualitative data collection and analysis in mixed method implementation research. Administration and Policy in Mental Health 42 (5): 533-544. https://doi.org/10.1007/s10488-013-0528-y.

Pawar, M. 2006. "Social” "capital”? The Social Science Journal 43 (2): 211-226.

Razavi, S. and Miller, C. 1995. From WID to GAD: conceptual shifts in the women and development discourse UNRISD Occasional Paper 1 Geneva UNRISD.

Ribeiro, M.M., and W. Zwirner. 2010. Applying participatory processes: findings from a supply chain analysis on the commercialisation of paper mulberry bark in Laos. Systemic Practice and Action Research 23 (4): 323-340.

Sari, I. McDougall, C. and Rajaratnam, S. 2017. Women's empowerment in aquaculture. Two case studies from Indonesia. Engagement, outcomes and constraining and enabling factors for women in shrimp farming and fish processing FAO and International Centre for Living Aquatic Resources Management (ICLARM) ISBN 978925-1-09859-2

Schmitz, H. 1999. Collective efficiency and increasing returns. Cambridge Journal of Economics 23 (4): 465-483. https://doi.org/ $10.1093 / \mathrm{cje} / 23.4 .465$.

Williams, M.J. 2008. Why look at fisheries through a gender lens? Development 2008 (51): 180-185. https://doi.org/10.1057/dev. 2008.2.

Worldfish. 2013. Improving food security and reducing poverty through intra-regional fish trade in sub-Saharan Africa CRIS No.DCIFOOD2012/309-438 EU Fish Trade_e3b_applicform_en 1 28Aug2013.

Yin, R. 1994. Case study research: design and methods. 2nd ed. Beverly Hills: Sage Publishing.

Publisher's note Springer Nature remains neutral with regard to jurisdictional claims in published maps and institutional affiliations. 